ECONOMIC THEMES (2019) 57(4): 397-413

\title{
DETERMINANTS OF INCOME INEQUALITY IN EU CANDIDATE COUNTRIES: A PANEL ANALYSIS
}

\section{Vesna Bucevska}

Ss. Cyril and Methodius University in Skopje, Faculty of Economics

Republic of North Macedonia

$\triangle$ vesna.bucevska@eccf.ukim.edu.mk

\section{UDC}

330.566:314.

143

(4-672EU)

Review

paper

\begin{abstract}
Despite increasing income per capita, the EU candidate and potential candidate countries remain confronted with high levels of income inequality. The purpose of our paper is to identify the main determinants of income inequality among the EU candidate countries. In addition to macroeconomic factors, we also analyze the impact of demographic variables to provide more reliable estimates. Using panel data analysis with fixed effects in the period 2005-2017 for three EU candidate countries (North Macedonia, Serbia and Turkey) we find that the unemployment rate, the level of economic development and the investment rate are the main determinants whose increase leads to a bigger income differentiation in the analyzed countries. The government indebtedness has also a statistically significant, but a negative impact on income inequality. The other two macroeconomic variables in the model - the terms of trade and inflation are statistically insignificant. Among the demographic factors, population growth and education significantly affect income inequality among the EU candidate countries. The obtained results suggest that a sustainable economic growth combined with active measures in the labor market and the improvement of education level of the population could lead to more equal income distribution.
\end{abstract}

Keywords: income inequality, panel data, macroeconomic factors, demographic factors, EU candidate countries.

JEL classification: O15, E60

\section{Introduction}

Rising income inequality is a global concern and therefore one of the most discussed economic, social and political issues. The gap between the rich and the poor is at its highest level for decades in advanced economies, while the inequality 
trends have been more mixed in emerging markets and developing countries (Dabla-Norris et al. 2015). This is especially true for the EU candidate and potential candidate countries, where Gini coefficients of equalized disposable income are higher than the value observed for the EU-28, suggesting that income disparities are greater in these countries.

Not surprisingly then, the extent of inequality, its drivers and how to handle them have become some of the most heated debate issues by policymakers and researchers alike.

One of the reasons for the high level of income inequality in the EU candidate and potential candidate countries is that all of them (with exception of Turkey) had undergone a long and painful transition process from planned to market economy. With respect to macroeconomic performance, most of them experienced the ' $U$ shaped' path of the gross domestic product and industrial production (Boeri and Terrell, 2002), with drops in output and increased unemployment and inflation in the first half of the 1990s, and macroeconomic stabilization and recovery in the second half of the 1990s. Privatisation and restructuring of the state-owned firms and closing down of a large number of non-profitable large-scale industrial companies resulted with a reallocation of a substantial part of the employees from the manufacturing and agricultural sectors towards the expanding service sector (Blanchard, 1997). However, the emerging private sector was not strong enough to create so many new jobs that could absorb the huge number of workers laid-off from the restructured state-owned firms. At the same time, a significant problem was the mismatch between the skill requirements of the newly created jobs and the actual skills owned by the workers (Svejnar, 2002). Workers laid off from declining industries had difficulty finding jobs in new industries due to skill mismatches, and many ended up locked in informal employment (Lehmann, 2014 and Slonimczyk, 2014). As a result, the labour markets in the first half of 1990s became less dynamic, leading to increases in unemployment and especially longterm unemployment and income inequality. The pace of labor market reforms differed among countries. In the Central European countries by the late 1990s, the unemployment declined and employment rates started to recover as a result of the aggressive upfront deregulation and large-scale enterprise restructuring. Similar trends were witnessed in the Baltics and SEE EU countries. In contrast, in CIS countries employment creation was modest and employment rates continued to fall. The Western Balkan countries have struggled with extremely high rates of unemployment and low rates of employment throughout the transition period as a result of deep structural factors (Roaf, et al., 2014).

The pace of labor market reforms differed among countries. Central European countries were fairly aggressive in upfront deregulation and large-scale enterprise restructuring. This led to large job losses, but by the late 1990s these reforms started to pay off as unemployment declined and employment rates started to recover. Similar trends were witnessed in the Baltics, which saw large cyclical 
swings between employment and unemployment through the transition, and SEE EU countries. In contrast, postponing layoffs in CIS countries may have helped to reduce labor market congestion, but at a cost of less job creation in the higher productivity private sector. As a result, employment creation was modest and employment rates continued to fall. In the Western Balkans, the high rates of unemployment and the low rates of employment persisted throughout the transition, pointing to deep structural factors.

Governments also could not maintain the pension entitlements and other social benefits of the socialist era. Inequality has also risen across these countries. The main increase took place in the initial stages of transition, with smaller rises (or in some cases reductions) in inequality indicators eversince (Roaf, et al., 2014). In the early 2000s, these countries had gradually improved their economies with a successful implementation of economic reforms. Despite economic growth during 2002-2006, poverty had not fallen. Moreover, rapid growth led to large increases in inequality (as measured by the Gini index). While in absolute terms everyone became better off, disparities in income distribution increased as the income share of the top quintile rose relative to the income share of the bottom quintile. Income inequality in the EU candidate and potential candidate countries had since declined, although it remains high, particularly in Bosnia and Herzegovina and Macedonia.

The economic boom of the transition countries was closely associated with the accession of eight countries in 2004 and two countries in 2007 to the European Union. The effects of this most significant expansion of the EU since its foundation, for the new member states, as well as for the EU itself, were enormous. The opening of labor markets has led to migration of about 2-3 million people from the new member states to the old ones. The economic benefits of these moves seem to have accrued mainly to the recipient countries, with a negative growth impact in the source countries (Holland et al., 2011).

The global financial crisis, which began in the developed economies in the summer of 2007, spread to the EU candidate and potential candidate countries with a time lag. Ater the collapse of Lehman Brothers in September 2008, capital inflows to these countries came to a sudden stop, which contributed to deep recessions as the lack of new funding triggered declines in credit and domestic demand (Roaf, et al., 2014). Wage reductions and a decline of remittances lead to worsening of the population's living standards and the increase of the number of poor people. In contrast to the pre-crisis period, when growth was robust, but poverty stagnant, poverty indicators in the aftermath of the global financial crisis of 2008 indicate an improvement in the living conditions of the bottom of the income distribution. However, despite the reduction of the poverty rate, poverty and inequality are still high when compared to other countries with similar levels of GDP per capita in the region. Figure 1 presents available information on Gini coefficients for the European Union countries and the EU candidate and potential candidate countries. 
Figure 1: Gini coefficient of equalized disposable income in 2017 in the $E U$ and the $E U$ candidate countries

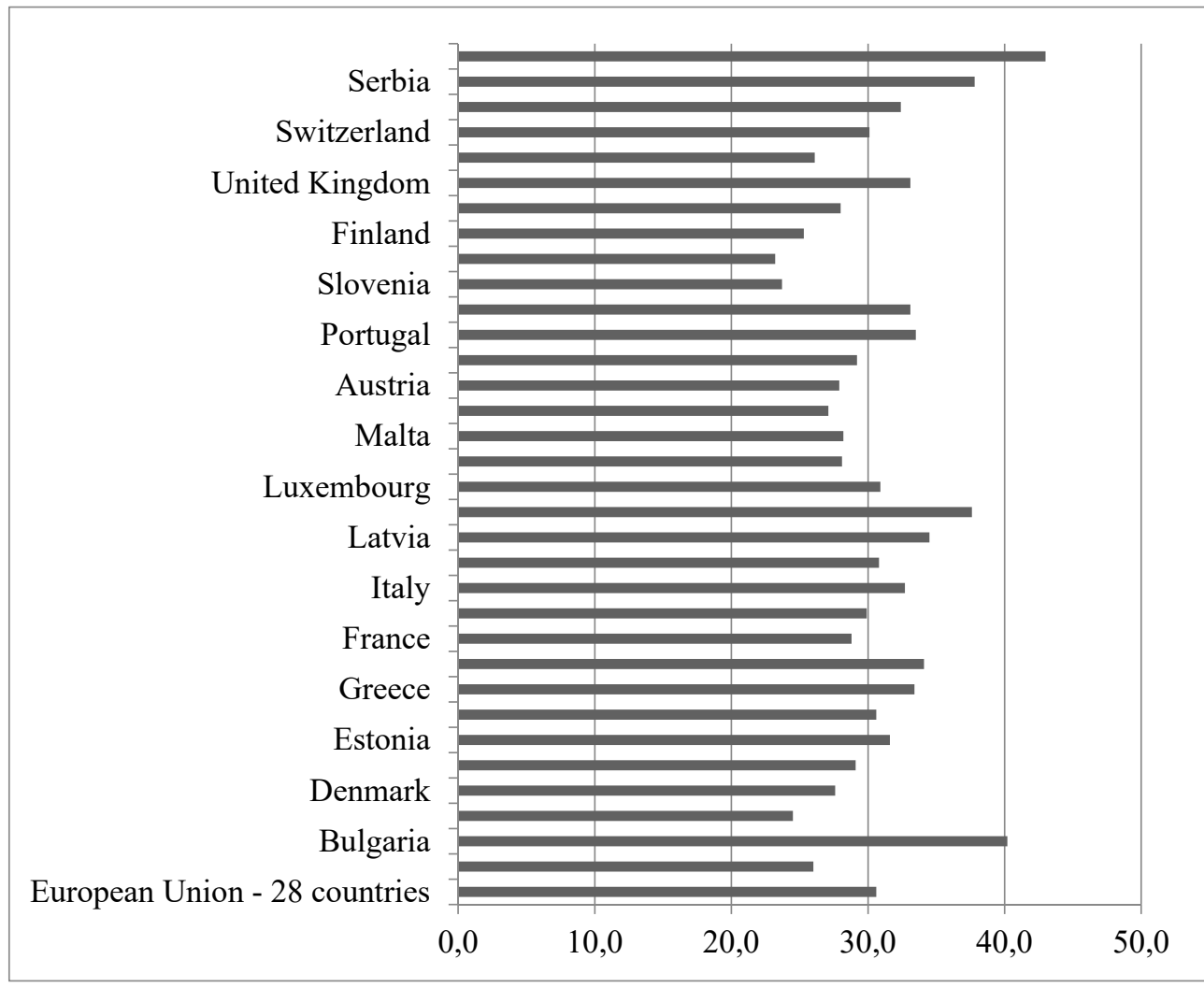

Source: European Union statistics on income and living conditions (EU-SILC) survey

As Figure 1 illustrates, Turkey and Serbia (42.6\% and $37.8 \%$, respectively) experienced the highest levels of inequality in equivalised disposable income in 2017, and the Gini coefficient for Macedonia (32.4) was also above the one for the EU-28 (30.7\%). High Gini coefficients were also recorded in the EU member states Bulgaria and Lithuania ( $40.2 \%$ and $37.6 \%$, respectively).

The Gini coefficient displays different trends for the EU candidate countries (see Figure 2) in the period 2005-2018. The Gini coefficient based on disposable income per capita in Serbia had a decreasing trend until 2013, when it significantly increased (from 28.2 in 2012 to 38 in 2013), after which it stabilized around 38, which is above the average for the EU-28. Macedonia saw a $32 \%$ reduction of income inequality in the period 2005-2017, but this trend was stopped in 2018 when the Gini coefficient of equalized disposable income slightly increased from 32.4 in 2017 to 36.1 in 2018. As noted in Figure 2, this coefficient for Turkey remained stable (around 40), but it was still high above the EU-28 average. 
Figure 2: Gini coefficient of equalized disposable income in EU-28 and the EU candidate countries in the period 2005-2018

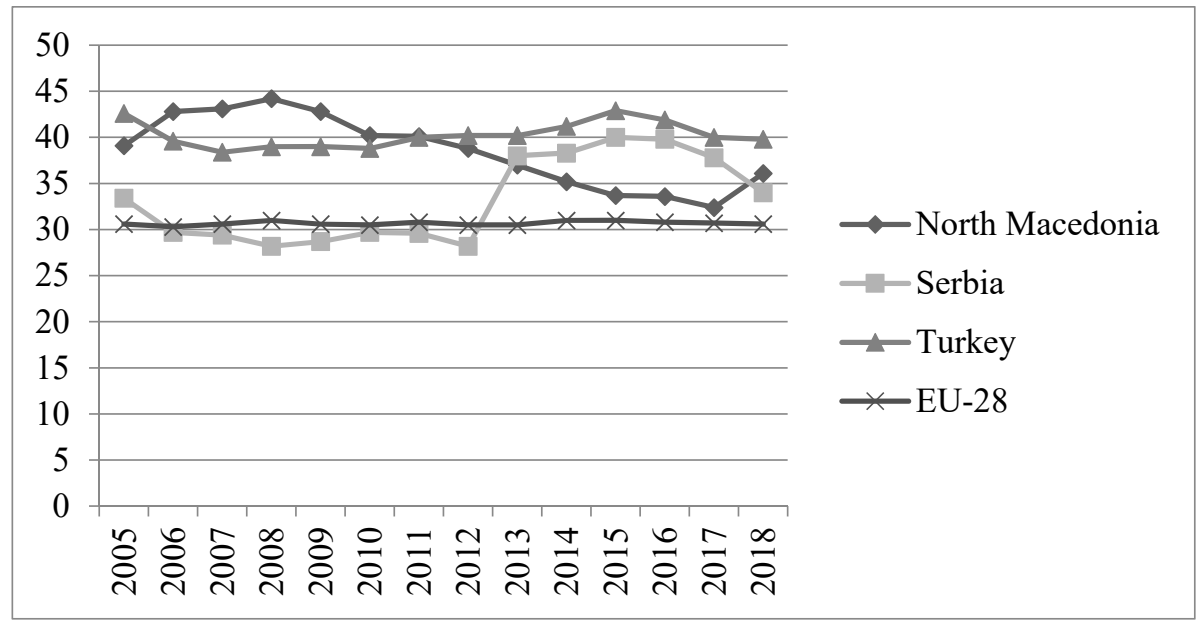

Source: Eurostat

There is an extended literature analyzing the relationship between income inequality and macroeconomic factors, such as the level of economic development, inflation rate, trade openness etc. However, as we will see in Section 2, the results of the empirical studies are ambiguous. Apart from the mixed findings on the linkages between inequality and macroeconomic determinants, the majority of the empirical studies is based on transition economies in Central and Eastern Europe, and not the EU candidate countries. Hence, the purpose of this paper is to examine and identify the crucial determinants of income inequality in the EU candidate countries. In order to provide more appropriate policy recommendations, in our study we consider not only macroeconomic factors, but also demographic variables. To the best of our knowledge, this is the first attempt to analyze determinants of income inequality in the EU candidate countries in a comparative manner using recent methodological techniques.

The next section lists possible macroeconomic factors, which are the most often cited as the drivers of income inequality, as well as some demographic variables. In particular, it reviews the empirical studies about their link to income inequality. Section 3 explains the econometric methodology, used in this paper, to assess the empirical link between macroeconomic and demographic factors and income inequality. Section 4 presents the data and results that we found with our dataset and methodology. In Section 5 we give conclusions and policy recommendations. 


\section{Literature review}

Based on the literature review, we identify the following macroeconomic factors affecting income distribution: economic development level, government expenditures, investment rate, inflation, unemployment and trade openness, as well as some demographic variables, such as education and the growth rate of population.

The economic development level measured by GDP per capita is one of the most significant macroeconomic factors of income inequality and hence many researchers have examined the relationship between income inequality and economic growth, but, until now, there is still no consensus. Kuznets (1955) found a parabolic relationship between income and inequality, according to which countries shift from relative equality to inequality and back to greater equality as they move through economic development stages. The graphical representation of this concept, known as the Kuznets curve, shows an inverted U-shape for the link between GDP per capita and income inequality. Milanovic (1994) investigated the factors that affect income distribution. He tested Kuznets' hypothesis according to which government policies can significantly change income distribution and proved the stance that Kuznets holds. Other researchers have found a negative relationship between income and inequality [Persson and Tabellini (1994), Alesina and Rodrik (1994), and Alesina and Perotti (1996)] or a nonlinear relationship between economic growth and inequality and stressed that economic growth negatively affects poor and positively affects rich countries [Barro (2000)]. Other authors [Bruno et al. (1996), Fishlow (1995), Ravallion (1995), and Deininger and Squire (1997)] have stated that there is no significant relationship between income and inequality. More recent empirical studies reject Kuznets' hypothesis more clearly [Hossain (2013), Lim and Sek (2014) and Monnin (2014)].

The impact of government expenditures on income inequality, proxied by government debt as percentage of GDP, has been studied by Calderon and Serven (2004) who, based on the panel of Latin American countries, found out that government-financed projects in infrastructure provide a source of employment and income, especially for low-skilled workers and in turn they contribute to reducing inequality. Contrary to Calderon and Serven (2004), who analyzed countries with the highest level of inequality, Chatterjee and Turnovsky (2004) discovered that government investment increases inequality over time, regardless of its source of financing. Maestri and Roventini (2012) further found that the comovements between inequality series and government consumption are heavily dependent on the institutions of the analyzed countries.

Investment rate, proxied by gross fixed capital formation, as a percentage of GDP, is another macroeconomic factor influencing income distribution. Sarel (1997) found that, when controlling other variables, higher investment rates reduce income inequality. In his bestseller, Piketty (2014) detected that inequality rises, as 
the share of national income derived from capital investment increases, and the share going to wages decreases income growth at all levels. Maldonado (2017) found that the investment rate influences income growth at all levels.

The theory, as well as empirical studies, do not give a clear answer whether inflation rate increases or decreases income inequality. The results of the more recent empirical studies on this topic are also mixed. According to Beetsma and Van Der Ploeg (1996), Al-Mahrubi (1997), Amornthum (2004), Bouvet (2010) and Albanesi (2007), inflation rate has a positive impact on income inequality. Other researchers, Maestri and Roventini (2012) and Coibion et al. (2012) found that inflation reduces income inequality.

The impact of unemployment on income inequality is widely studied in the literature. However, empirical evidence on the link between unemployment and income distribution is mixed. The increase of unemployment usually affects the people in the lower tail of the personal income distribution, thus lowering per capita income (Levernier, et al., 1995). Checchi and Garcia-Penalosa (2008) and Maestri and Roventini (2012) documented that higher unemployment rates increase inequality in OECD countries. Bandelj and Mahutga (2010) found a negative relationship between unemployment and GDP in logarithmic terms, as a coefficient against inequality for post-socialist countries. On the other hand, Castaneda, Diaz Gimenez and Rios-Rull (1997) and Ekill (2011) did not find any significant relationship between unemployment and Gini coefficients.

Globalization and trade openness may also influence international inequality. However, the obtained empirical results are ambiguous. Wood (1994), Bourguignon and Morrisson (1990), Reuveny and Li (2003), Calderón and Chong (2001) and Dollar and Kraay (2001 and 2004) have found income inequality decreased after the trade liberalisation. Recently, Lim and McNelis (2014) find that trade openness increases income inequality in a sample of 42 countries between 1992 and 2007. Other researchers did not document any significant relationship between openness and income inequality (Edward, 1997; Li, Squire and Zou, 1998 and Vivarelli, 2004) or clearly stated that globalization and trade liberalization increase income inequality [Barro (2000), Cornia and Kiiski (2001), Lundberg and Squire (2003), Easterly (2005) and Milanovic and Squire (2005)].

The impact of education on income inequality remains ambiguous in the empirical research. According to Breen and Garcia-Penalosa (1999) the higher educational attainment significantly reduces income inequality, both in developed and developing countries. Li et al. (1998), Barro (2000), Checchi (2000), De Gregorio and Lee (2002), Gunatilaka and Chotikapanich (2005) find empirical evidence to support the idea that the rise in educational level contributes to more equal income distribution. Contrary to them, Mughal and Diawara (2011) investigated the relationship between human capital and economic inequality in the developing countries and found that primary, secondary and tertiary level 
education is negatively associated with inequality. Wells (2006) has shown that the effects of education on income inequality are affected by the level of economic freedom in a country, and, specifically, that more economic liberalisation may limit the equalising effects of secondary enrolments. Rehme (2007) has found that education simultaneously affects growth and income inequality and that increases in education first increase and then decrease growth, as well as income inequality, when measured by the Gini coefficient.

Population processes are expected to contribute to global income inequality. Alderson and Nielsen (1995) indicated that a relatively high population growth may increase income inequality. According to Deaton and Paxson (1997), a decrease in the population growth rate redistributes population toward older, more unequal cohorts, and it can lead to national inequality.

The reviewed existing literature clearly highlights significant methodological drawbacks (most of the empirical studies are purely based on conventional time series and cross-section analysis), as well as the unavailability of consensus on the linkages between inequality and its determinants. Sarel (1997) highlighted the need to expand the empirical framework from cross-sectional analysis to panel data analysis and to include some demographic variables, such as education.

\section{Methodology, data and model specification}

In this paper we have adequately addressed the necessary modifications, highlighted by Sarel (1997), by using panel data analysis and including demographic explanatory variables in the estimated model. These countries have been selected based on the availability of data for the selected variables. The analyzed period 2005-2017 includes years before, during and after the latest global financial and economic crisis, thus enhancing the power of our estimates regarding the impact of the global financial crisis on the income inequality.

We estimate a model based on balanced panel data for three EU candidate countries (North Macedonia, Serbia and Turkey), which means that the period is the same for each country. As our sample consists of countries with different macroeconomic and political conditions, we are going to apply more sophisticated specifications than the OLS estimation. We use the panel data estimation method which has several advantages. Unlike a cross-section or a pure time-series analyses, the most important methodical advantage of panel data estimation is that it allows one to control the effects of missing or unobservable time-invariant country-specific variables. The fact that we are dealing with small number of cross section units gives advantage to the fixed effect model, in comparison to a random effects model. Another reason for choosing the fixed effects model is that it helps alleviate potential heteroscedasticity problems stemming from possible differences across countries (Greene, 2012). Unlike the random effects model, which assumes 
that country-specific terms are uncorrelated with the other independent variables and violation of this assumption makes random effects estimates biased and inconsistent (Greene, 2012), the fixed effects model avoids this problem by allowing individual effects to be correlated with other regressors. However, the main reason for choosing the fixed effects model is to accomplish the objective of our paper - to investigate the macroeconomic factors that affect inequality in the EU candidate countries over time and to identify the key determinants of inequality within these countries, and not to explain variation in inequality across countries. The fixed effects model is also more suitable when the focus is on a specific set of countries and the inference is restricted to these countries (Baltagi, 2013). Specifically, the empirical model explained in Equation 1 has been used to model the macroeconomic determinants of income inequality of selected EU candidate countries:

$$
\begin{aligned}
\text { GINI }= & \beta_{0, i t}+\beta_{1, i t}, \log (G D P)+\beta_{2, i t} D E B T+\beta_{3, i t} \text { GRRATECAPITAL }+ \\
& \beta_{4, i t} \text { INFLATION }+\beta_{5, i t} \text { UNEPLOYMENT }+\beta_{6, i t} \text { TOT }
\end{aligned}
$$

In Equation (2) besides all above mentioned macroeconomic determinants, we have added two demographic factors: education and population growth.

$$
\begin{gathered}
\text { GINI }=\beta_{0, i t}+\beta_{1, i t}, \log (G D P)+\beta_{2, i t} D E B T+\beta_{3, i t} \text { GRRATECAPITAL }+ \\
\beta_{4, i t} I N F L A T I O N+\beta_{5, i t} U N E P L O Y M E N T+\beta_{6, i t} \text { TOT }+\beta_{7, i t} \text { EDUC }+ \\
\beta_{8, i t} P O P+u_{, i t}
\end{gathered}
$$

The Gini coefficient is a leading indicator for measuring income inequality. It is derived from the Lorenz curve and defined as the ratio of the area between the Lorenz curve and the perfect equality line. The Lorenz curve plots the relation between the cumulative percentage of the population and the proportion of total income earned by each cumulative percentage. The Gini coefficient varies from 0 , corresponding to perfect equality to 100 , corresponding to perfect inequality. A lower Gini coefficient reflects a more egalitarian distribution of income. The growth rate of the Gini index (GINI) is the dependent variable in our model. The vector of explanatory variables includes macroeconomic variables, such as the log of gross domestic product (lnGDP), growth rate of government debt as a percentage of GDP (DEBT), growth rate of fixed capital formation as a percentage of GDP (GRRATECAPITAL), inflation (INFL), unemployment (UNEMP) and growth rate of terms of trade (TOT) as well as demographic variables, such as, education (EDUC) and growth rate of population (POP). The data set is collected from different sources. The source for the inequality index is the Poverty and Equity Data Portal of the World Bank Group and the data for macroeconomic and demographic variables are collected from EUROSTAT database. The econometric analysis has been performed using the statistical software product EViews 9. 


\section{Estimation and results}

The main results from the conducted regression analysis are presented in Table 1. We have estimated two regression models: the first has only the macroeconomic determinants as regressors, while in the second we have also added some demographic determinants, such as population growth and education. It is evident from Table 1 that the F-statistics for both models show good general results and for the second model it is statistically significant at almost $2 \%$ level of significance. The coefficient of determination for model $(2)$ has a solid value $(\mathrm{R}$ Square $=0.527)$ and it shows that $52.7 \%$ of the change in Gini coefficient during the period 19902015 can be explained with the changes in independent variables included in the model.

Table 1: Estimation results

\begin{tabular}{|r|r|r|}
\hline & Model 1 & \multicolumn{1}{|c|}{ Model 2 } \\
\hline C & $\begin{array}{r}-168.7181^{* *} \\
(72.50372)\end{array}$ & $\begin{array}{r}-381.8447^{* * *} \\
(119.9687)\end{array}$ \\
\hline LOG(GDP) & $16.45944^{* *}$ & $39.70503^{* * *}$ \\
& $(7.903348)$ & $(0.094725$ \\
\hline DEBT & $-0.211617^{* *}$ & $-0.242099^{* * *}$ \\
& $(0.099444)$ & $(13.27415)$ \\
\hline GRRATECAPITAL & $-0.472673^{* * *}$ & $-0.520487 * * *$ \\
& $(0.147523)$ & $(0.141495)$ \\
\hline INFLATION & -0.489151 & -0.153283 \\
& $(0.457333)$ & $(0.454348)$ \\
\hline UNEMPLOYMENT & $1.597726^{* * *}$ & $2.227698^{* * *}$ \\
& $(0.442086)$ & $(0.513359)$ \\
\hline \multirow{2}{*}{ TOT } & -0.194412 & -0.084998 \\
& $(0.181307)$ & $(0.00000338)$ \\
& & \\
\hline
\end{tabular}




\begin{tabular}{|r|r|r|}
\hline EDUC & & $\begin{array}{r}-6.55 \mathrm{E}-06^{*} \\
(15.51290)\end{array}$ \\
\hline POP & & $\begin{array}{r}33.89723^{* *} \\
(0.177119)\end{array}$ \\
\hline $\mathrm{R}^{2}$ & 0.424184 & 0.527187 \\
\hline Breusch-Pagan LM & 2.024917 & 4.331910 \\
\hline JB & & 0.468687 \\
\hline Cross-section F & 11.23598 & 7.546620 \\
\hline df & 5.640046 & $(2,27)$ \\
\hline prob & 2 & 0.0019 \\
\hline prob & 0.0090 & 17.003950 \\
\hline square & 12.567352 & $(2,25)$ \\
\hline df & & 0.0027 \\
\hline & 0.0019 & \\
\hline
\end{tabular}

Source: Author's own calculations

Our empirical analysis shows that the most significant macroeconomic factors of income inequality at $1 \%$ level of significance are unemployment, GDP per capita, gross fixed capital formation and debt. Higher unemployment rate increases the income inequality in the analyzed countries which is consistent with the finding of Jantti and Jenkins (2001). They argued that unemployment may reduce the income share of the third income quantile to the richest quantile, while increasing the income share of the poorest quantile and the second.

GDP, as expected, positively affects income inequality, indicating a parabolic relationship between GDP and income inequality. Namely, an increase in income increases inequality up to some extent and reduces inequality thereafter. This finding is consistent with Kuznets (1955) and Barro (2000). It indicates that in the early stages of the economic growth, income distribution is more unequal, and with further increase of GDP in a long run, this inequality is gradually reduced. 
Gross fixed capital formation, as a percentage of GDP, has a significant effect on reducing income inequality in the EU candidate countries, which is in compliance with Calderon and Serven (2004) who observed that investment in infrastructure stimulates economic growth and in turn, reduces inequality.

Regarding the impact of government debt, the results show that the growth rate of the government debt, as a share of GDP, has a strong and negative impact on the income distribution in the EU candidate countries. This finding is in line with the usually stated negative distributional impact of government debt. Namely, a rise in government debt may increase the income of the workers resulting in redistribution from capitalists to the workers and decrease in personal income inequality (You, JI. and Dutt, A. K., 1996).

Furthermore, the study highlighted that the macroeconomic variables - terms of trade and inflation have no statistically significant impact on the income distribution in the EU candidate countries.

From a demographic point of view, the study empirically confirmed that population growth has a positive and statistically significant impact on the income inequality in the analyzed countries, which is consistent with Alderson and Nielsen (1995) who indicated that a relatively high population growth may increase income inequality. Also, education has a negative and significant (at 10\% level) influence on the level and dynamics of income inequality in the EU candidate countries, which is in line with Breen and Garcia-Penalosa (2005), Barro (2000), De Gregorio and Lee (2002) who stressed that higher educational attainment leads to decreasing the differentiation in payment.

Furthermore, we have also conducted some diagnostic tests for both models. Namely, the results from Breusch-Pagan test show that, in both models, there is no evidence of existence of serial correlation. The result of Jarque-Berra test in Model 2 is in favor of hypothesis of normal distribution of residuals, while in Model 1 this hypothesis can be rejected. The two statistic values of $\mathrm{F}$ test and $\chi^{2}$ test for Model 2 (7.546620 and 17.003950) and the associated p-values strongly reject the null that the cross-section effects are redundant. The same results hold also for Model 1.

\section{Conclusions and policy recommendations}

The purpose of our paper has been to identify the main determinants of income inequality in the EU candidate countries (North Macedonia, Serbia and Turkey) for the period 2005-2017. The results of our econometric study show that unemployment, GDP per capita and the share of gross fixed capital formation in GDP are the most statistically significant macroeconomic variables, whose increase leads to a bigger income differentiation. We also find out that growing indebtedness of the EU candidate states has a strong and negative distributional impact. The other two macroeconomic variables in the model - terms of trade and 
inflation are statistically insignificant. Among the demographic factors, population growth and education level significantly reduce income inequality in the EU candidate countries.

The obtained results suggest that active measures in the labor market related to education, the requalification of the workforce and ensuring employment, combined with a steady long-term economic growth are of essential importance for more equal income distribution. It is also important to improve the education level, as the increase of income with the poorer part of population should be expected from enhancing education, qualification and the productivity of workers.

\section{References}

Albanesi, S. (2007). Inflation and inequality. Journal of Monetary Economics 54(4), pp. 10881114.

Alderson, A. S., and Nielsen, F. (1995). Income inequality, development and dualism: Results from an unbalanced cross-national panel. American Sociological Review 60, pp. 674 701.

Alesina, A. and Rodrik, D. (1994). Distributive politics and economic growth. Quarterly Journal of Economics, 109, pp. 465-490.

Alesina, A. and Perotti, R. (1996). Income distribution, political instability, and investment. European Economic Review 40(6), pp. 1203-1228.

Al-Marhubi, F. A. (1997). A Note on the Link between Income Inequality and Inflation. Economics Letters 55, pp. 317-319.

Amornthum, S., (2004). Income Inequality, Inflation and Nonlinearity: The Case of Asian Economies. Retrieved from: http://www2.hawaii.edu/ amornthu/pdf/Paper610.pdf. 4, Accessed on 7th October 2019.

Baltagi, B. (2013). Econometric Analysis of Panel Data. 5th Edition. Wiley, Chichester.

Bandelj, N. and Mahutga, M. C. (2010). How Socio-Economic Change Shapes Income Inequality in Post-Socialist Europe? Social Forces, Volume 88, Number 5, pp. 21332161.

Barro, R. J. (2000). Inequality and Growth in a Panel of Countries, Journal of Economic Growth, Springer, Vol. 5(1), March 2000, pp. 5-32.

Beetsma, R. M. J. and Ploeg, V. D. F. (1996). Does Inequality Cause Inflation? The Political Economy of Inflation, Taxation and Government Debt. Kluwer Academic Publishers 87, pp.143-162.

Blanchard, O. (1997). The Economics of Post-Communist Transition. Oxford: Clarendon Press.

Boeri, T. and Terrell, K. (2002). Institutional determinants of labor reallocation in transition. Journal of Economic Perspectives 16:1, pp. 51-76.

Bourguignon, F. and Morrisson, C. (1990). Income distribution, development and foreign trade. European Economic Review Vol. 34, pp. 1113-1132.

Bouvet, F. (2010). EMU and the Dynamics of Regional per Capita Income Inequality in Europe. Journal of Economic Inequalities No. 8, pp. 323-344.

Boyd, R. L. (1988). Government Involvement in the Economy and the Distribution of Income: A Cross-National Study. Population Research and Policy Review 7, pp. 223238. 
Breen, R. and García-Peñalosa, C. (2005). Income inequality and Macroeconomic Volatility: An Empirical Investigation. Review of Development Economics 9(3), 2005, pp. 380 398.

Bruno, M., Ravallion, M. and Squire, L. (1996). Equity and Growth in Developing Countries: Old and New Perspectives on the Policy Issues. Policy Research Working Paper Series Vol. 1563, Washington DC: World Bank.

Calderon, C. and Chong, A. (2001). External sector and income inequality in interdependent economies using a dynamic panel data approach. Economics Letters, Vol. 71(2), pp. 225-231.

Dollar, D. and Kraay, A. (2001). Growth Is Good for the Poor. World Bank Policy Research Working Paper Series No. 2587, World Bank, Washington DC.

Calderon, C. and Serven, L. (2004). The Effects of Infrastructure Development on Growth and Income Distribution. World Bank Policy Research Working Paper Series No. 270, Washington DC: World Bank.

Castaneda, A., Diaz-Gimenez, J. and Rios-Rull, J.V. (1998). Exploring the income distribution business cycle dynamics. Journal of Monetary Economics, 42(1), pp. 93-130.

Chatterjee, S. and Turnovsky, S. J. (2012). Infrastructure and Inequality. European Economic Review, Vol. 56, Issue 8, November, pp. 1730-1745.

Checchi, D. and Garcia-Penalosa, C. (2008). Labor Market Institutions and Income Inequality. Economic Policy No. 23(56), pp. 601-649.

Coibion, O., Gorodnichenko, Y., Kueng, L. and Silvia, J. (2012). Innocent Bystanders? Monetary Policy and Inequality in the U.S. NBER Working Paper Series, No 18170.

Cornia, G.A. and Kiiski, S. (2001). Trends in Income Distribution in the Post World War II Period: Evidence and Interpretation. UNU/WIDER Discussion Papers 89, UNU/WIDER, Helsinki, Finland.

Dabla-Norris, E., Kochhar, K., Ricka, F., Suphaphiphat, N. and Tsounta, E. (2015). Causes and Consequences of Income Inequality: A Global Perspective. IMF Working Paper SDN/15/13. Washington, DC: International Monetary Fund.

De Gregorio, J. and Lee, J. W. (2000). Education and Income Inequality: New Evidence from Cross-Country Data. Review of Income and Wealth 48, pp. 395-416.

Deininger K., and Squire, L. (1997). Economic Growth and Income Inequality: Reexamining the Links. Finance and Development 34, pp. 38-41.

Deaton, A. and Paxson C. (1997). The Effects of Economic and Population Growth on National Saving and Inequality. Demography 34 (1), pp. 97-114.

Edwards, S. (1997). Trade Policy, Growth, and Income Distribution. The American Economic Review, Vol. 87 (2), Papers and Proceedings of the Hundred and Fourth Annual Meeting of the American Economic Association, pp. 205-210.

Easterly, W. (2005). Globalization, Prosperity, and Poverty, in Ann Harrison (editor), Globalization and Poverty, University of Chicago Press for NBER.

Erosa, A. and Ventura, G. (2002). On inflation as a regressive consumption tax. Journal of Monetary Economics 49(4), pp. 761-795.

Fishlow, A (1995). Inequality, Poverty and Growth, Where Do We Stand? OPS Document Reproduction Series 65, World Bank.

Greene, W. H. (2012). Econometric Analysis $7^{\text {th }}$ Edition. Pearson Education, Limited.

Gunatilaka, R. and Chotikapanich, D. (2006). Inequality Trends and Determinants in Sri Lanka 1980-2002: A Shapley Approach to Decomposition. No. 6/06. Monash University, Department of Econometrics and Business Statistics. 
Holland, D., Fic, T., Rincon-Aznar A., Stokes, L. and Paluchowski, P. (2011). Labour mobility within the EU-The impact of enlargement and the functioning of the transitional arrangements. National Institute of Economic and Social Research.

Hossain, S. (2013). Does economic development requires more income inequality?Is the Kuznets curve still valid?. Developing Country Studies, 3(8), pp. 196-205.

Jantti, M., and Jenkins, S. P. (2001). Examining the Impact of Macro-Economic Conditions on Income Inequality.

Kuznets, S. (1995). Economic Growth and Income Inequality. The American Economic Review 45(1), pp. 1-28.

Lehmann, H. (2014). Worker displacement in transition economies and in China. IZA World of Labor: 20, Bonn, Institute for the Study of Labor.

Li, H., Squire, L. and Zou, H. (1998). Explaining International and Intertemporal Variation in Income Inequality. The Economic Journal, Vol. 108, pp. 26-43.

Lim, G. C. and McNelis, P. (2014). Income inequality, trade and financial openness. New Perspectives.

Lim, C. Y. and Sek, S. K. (2014). Exploring the two-way relationship between income inequality and growth. Journal of Advanced Management Science 2(1), pp. 33-37.

Lundberg, M. and Squire, L. (2003). The Simultaneous Evolution of Growth and Inequality. Economic Journal Vol.113 (487).

Maestri, V. and Roventini, A. (2012). Inequality and macroeconomic factors: a timeseries analysis for a set of OECD countries. LEM Papers Series 2012/21, Laboratory of Economics and Management (LEM), Sant'Anna School of Advanced Studies, Pisa, Italy.

Maldonado, J. E. (2017). Financial Systems and Income Inequality. Bruges European Economic Research Papers 36/2017.

Milanovic, B. (1994). Determinants of Cross-Country Income Inequality An "Augmented" Kuznets' Hypothesis. The World Bank Policy Research Department Transition Economies Division Policy Research Working Paper 1246.

Milanovic, B. and Squire, L. (2005). Does Tariff Liberalization Increase Wage Inequality? Some Empirical Evidence. World Bank Policy Research Working Paper, No. 3571., World Bank, Washington, DC.

Monnin, P. (2014). Inflation and Income Inequality in Developed Economies. Working Papers 1401, Council on Economic Policies.

Mughal, M. Y. and Diawara, B. (2011). Explaining Income Inequalities in Developing Countries: The Role of Human Capital. Working Papers 2011-2012_2, CATT UPPA - Université de Pau et des Pays de l'Adour, revised Dec 2011.

Persson, T. and Tabellini, G. (1994). Is Inequality Harmful for Growth? The American Economic Review, pp. 600-621.

Piketty, T. (2014). Capital in the Twenty-First Century. Belknap Press.

Ravallion, M. (1995). Growth and Poverty: Evidence for Developing Countries in the 1980s. Economics Letters 48(3).

Rehme, G. (2007). Education, Economic Growth and Measured Income Inequality. Economica, Vol. 74, No. 295, pp. 493-514.

Reuveny, R and Li, Q. (2003). Economic Openness, Democracy, and Income Inequality: An Empirical Analysis. Comparative Political Studies, Vol. 36(5), pp. 575-601 
Roaf, J., Ruben, A., Joshi, B. and Krogulski, K. (2014) 25 years of transition: post-communist Europe and the IMF, International Monetary Fund Series: Regional economic issues special report. International Monetary Fund, Washington, D.C.

Sarel, M. (1997). How Macroeconomic Factors Affect Income Distribution: The CrossCountry Evidence. IMF Working Paper, Vol. , pp. 1-25.

Slonimczyk, F. (2014). Informal employment in emerging and transition economies. IZA World of Labor: 59, Bonn: Institute for the Study of Labor.

Stack, S. (1978). The Effect of Direct Government Involvement in the Economy on the Degree of Inequality: A Cross-National Study. American Sociological Review 43, pp. 880-888.

Svejnar, J. (2002). Transition Economies: Performance and Challenges, Journal of Economic Perspectives 16 (1), pp. 3-28.

Wells, R. (2006). Education's Effect on Income inequality: An Economic globalisation Perspective. Globalisation, Societies and Education 4(3), pp. 371-391.

Wood, A. (1994). North-South trade, employment, and inequality: Changing fortunes in a skill-driven world. Clarendon Press, Oxford.

Vivarelli, M. (2004). Globalization, Skills and Within-Country Income Inequality in Developing Countries, in Lee, E. and Vivarelli, M. (2004) (eds). Understanding Globalization, Employment and Poverty Reduction. Palgrave Macmillan, New York, pp. 211-243.

You, J-I. and Dutt, A. K. (1996). Government Debt, Income Distribution and Growth. Cambridge Journal of Economics, Oxford University Press, 20(3), pp. 335351, May.

\section{DETERMINANTE NEJEDNAKOSTI DOHOTKA U ZEMLJAMA KANDIDATIMA ZA C̆LANSTVO U EU: PANEL ANALIZA}

Rezime: Uprkos rastućim prihodima po glavi stanovnika, zemlje kandidati za članstvo u EU i zemlje potencijalni kandidati i dalje su suočene sa visokim nivoom nejednakosti dohotka. Svrha ovog rada je da identifikuje glavne determinante nejednakosti u dohotku među zemljama kandidatima za članstvo u EU. Pored makroekonomskih faktora, analiziran je i uticaj demografskih varijabli kako bismo pružili pouzdanije procene. Koristeći panel analizu podataka sa fiksnim efektima u periodu 2005-2017. za tri države kandidate za članstvo u EU (Severna Makedonija, Srbija i Turska), otkrivamo da su stopa nezaposlenosti, nivo ekonomskog razvoja i stopa ulaganja glavna odrednica čije povećanje dovodi do veće razlike u dohotku u analiziranim zemljama. Zaduženost države takođe ima statistički značajan, ali negativan uticaj na nejednakost prihoda. Ostale dve makroekonomske promenljive u modelu - uslovi trgovine i inflacija su statistički beznačajni. Među demografskim faktorima, rast stanovništva i obrazovanje značajno utiču na nejednakost prihoda među zemljama kandidatima za članstvo u EU. Dobiveni rezultati ukazuju na to da održivi ekonomski rast u kombinaciji sa aktivnim merama na tržištu rada i poboljšanjem nivoa obrazovanja stanovništva može dovesti do ravnomernije raspodele dohotka.

Ključne reči: nejednakost u prihodima, panel analiza, makroekonomski faktori, demografski faktori, zemlje kandidati za članstvo u EU 


\section{Author's biography}

Vesna Bucevska is a Full-time professor at the Faculty of Economics of Ss. Cyril and Methodius University in Skopje. She graduated from the Faculty of Economics in Skopje in 1993. In 1995 she enrolled in postgraduate studies in Statistical Analysis at the Faculty of Economics in Belgrade and in 1999 received the title of Master of Science in Statistics. In 2002 she received her $\mathrm{Ph} . \mathrm{D}$. degree in Economics at the Faciulty of Economics in Skopje. Her main research areas are statistics and econometrics. She published five textbooks and 120 papers in international scientific journals and won the award: "The best scientist at the University Sts. Cyril and Methodius in the field of social sciences in 2017." From 2013 to 2018 she was Vice-Dean of Science and International Cooperation at the Faculty of Economics. Vesna Bucevska is a member of the Statistical Council of the Republic of Macedonia. She is an Editorin-chief of "Journal of Contemporary Economic and Business Issues". 